\title{
REQUIREMENT FOR THIAMINE AMONG SOME MARINE AND SUPRA-LITTORAL PROTISTA
}

\author{
By M. R. DRoop \\ Marine Station, Millport, Scotland
}

(Text-fig. I)

It has been known for some years that a need for an exogenous source of thiamine exists among algal flagellates (Lwoff \& Lederer, 1935; Provasoli \& Pintner, 1953) and indeed the requirement coupled with one for $B_{12}$ is quoted as characterizing auxotrophic algae (Provasoli, McLaughlin \& Droop, 1957). Nevertheless, published data for marine species concerning thiamine are limited to a recent paper by J. J. A. McLaughlin (1958) which establishes an absolute requirement for thiamine on the part of Prymnesium parvum. The reason for this is partly due to interest in thiamine taking second place to interest in vitamin $B_{12}$ and partly to the fact that thiamine-free media are not easily prepared, so that the requirement for the vitamin appeared as stimulatory rather than absolute (Droop, 1953 $a$, 1957).

The following is an attempt to remedy this state of affairs as regards a few species maintained in bacteria-free culture at Millport.

The strains used

METHODS

In the first instance $B_{12}$ requiring strains were chosen for the study, then two known to have no $B_{12}$ requirement were added and finally some dinoflagellates on which there were no data (Table I).

\section{Culture media}

Basal media were as follows: for Skeletonema, $\mathrm{S}_{3} 6$ with thiamine omitted (Droop, I955b); for Hemiselmis, S 46 with thiamine omitted (Provasoli et al. 1957); and for the remainder, excepting Oxyrrhis, S 50 with thiamine omitted. $\mathrm{S}_{50}$ is given in full in Table 2 . It differs from my previously published media chiefly in the composition of the trace metal mixture and the replacement of the $\mathrm{pH}$ buffer tris(hydroxymethyl)aminomethane by glycylglycine (which is very much less toxic to some species than TRIS) and glycine (which increases the buffering of the medium in the region of $\mathrm{pH}$ 9-10).

The media for Oxyrrhis are to be discussed fully in a paper on the nutrition of this species shortly to be published. Thiamine data are included here for the sake of completeness. 
Both stocks and experimental cultures were kept in Pyrex test-tubes I $5 \times 150 \mathrm{~mm}$. Oxo aluminium test-tube caps were employed to begin with, but were replaced by cotton wool when it was realized that contamination from this source was certainly less than Io $\mathrm{m} \mu \mathrm{g} / \mathrm{l}$.

TABLE 1. STRAINS USED

(Millport reference numbers in parentheses)

Chrysophyceae

Monochrysis lutheri

Prymnesium parvum Carter

Syracosphaera elongata

Microglena arenicola

Cryptophyceae

Hemiselmis virescens

Chlorophyceae

Nannochloris oculata

Bacillariophyceae

Skeletonema costatum (Grev.) Cleve

Phaeodactylum tricornutum Bohlin (syn.

Nitzschia closterium f. minutissima (W. Smith) Allen \& Nelson)

Dinophyceae

Glenodinium foliaceum Stein

Peridinium trochoideum (Stein) Lemm.

Oxyrrhis marina Dujardin $\begin{array}{ll}\text { (60) } & \text { Droop, I953a, I954 } \\ \text { (65) } & \text { Droop, I954 } \\ \text { (62) } & \text { Droop, I954, I955a } \\ \text { (72) } & \text { Droop, I955a, I957 }\end{array}$

(64) Droop, r955a, r957

(66) Droop, I955a

(73) Plymouth strain, Droop, $1955 b$

(14) Finnish strain, Droop, r953a

(47) Finnish strain, Droop, r953a

(88) From the Clyde

(I8) Finnish strain, Droop, r953b

TABLE 2. MEDIUM S50

\begin{tabular}{|c|c|c|c|c|c|c|c|}
\hline $\begin{array}{l}\mathrm{NaCl} \\
\mathrm{MgCl}_{2} 6 \mathrm{H}_{2} \mathrm{O} \\
\mathrm{KCl} \\
\mathrm{CaSO}_{4} 2 \mathrm{H}_{2} \mathrm{O}\end{array}$ & $\begin{array}{l}15 \mathrm{~g} \\
2.5 \mathrm{~g} \\
400 \mathrm{mg} \\
500 \mathrm{mg}\end{array}$ & $\begin{array}{l}\mathrm{Br} \\
\mathrm{Sr} \\
\mathrm{Al} \\
\mathrm{Rb} \\
\mathrm{Li} \\
\mathrm{I}\end{array}$ & $\begin{array}{l}22 \mathrm{mg} \\
3.8 \mathrm{mg} \\
28 \mu \mathrm{g} \\
6 \mathrm{I} \mu \mathrm{g} \\
6.0 \mu \mathrm{g} \\
20 \mu \mathrm{g}\end{array}$ & $\begin{array}{l}\mathrm{Na}_{2} \text { EDTA } \\
\mathrm{Fe} \\
\mathrm{Mn} \\
\mathrm{Zn} \\
\mathrm{Cu} \\
\mathrm{Co} \\
\mathrm{Mo}\end{array}$ & $\begin{array}{l}50 \mathrm{mg} \\
500 \mu \mathrm{g} \\
50 \mu \mathrm{g} \\
5.0 \mu \mathrm{g} \\
5.0 \mu \mathrm{g} \\
500 \mathrm{~m} \mu \mathrm{g} \\
500 \mathrm{~m} \mu \mathrm{g}\end{array}$ & $\begin{array}{l}\text { Glycylglycine } \\
\text { Glycine } \\
\mathrm{KNO}_{3} \\
\mathrm{~K}_{2} \mathrm{HPO}_{4} \\
\mathrm{~B}_{12} \\
\text { Thiamine } \\
\mathrm{H}_{2} \mathrm{O} \text { to } \\
\text { pH adjusted to } 8\end{array}$ & $\begin{array}{l}500 \mathrm{mg} \\
250 \mathrm{mg} \\
100 \mathrm{mg} \\
10 \mathrm{mg} \\
100 \mathrm{~m} \mu \mathrm{g} \\
\mathrm{I} \cdot 0 \mathrm{mg} \\
\mathrm{I} \cdot 01 .\end{array}$ \\
\hline
\end{tabular}

Where possible, growth was measured optically, in which case it is expressed as percentage transmission or as OD $\times 100,\left(=100 \log _{10} \frac{100}{\% \text { transmission }}\right)$. It was necessary to count in other cases; growth is then expressed as cells per $\mathrm{mm}^{3}$.

\section{Serial transfer experiments}

RESULTS

The concentrations over which growth is a function of thiamine concentration in other micro-organisms is $0-500 \mathrm{~m} \mu \mathrm{g} / \mathrm{l}$. (Snell, I95I); and since my stock media contained up to I $\mathrm{mg} / \mathrm{l}$. of the vitamin, at least two transfers were necessary to reduce the concentration sufficiently in the blanks (cultures receiving no addition of the vitamin). This naturally depended on the size of the inoculum which was, therefore, made as small as possible. With Monochryses, Prymnesium, Syracosphaera, Microglena, Nannochloris, Phaeodactylum 
and Skeletonema the inoculum could be reduced to $0.02 \mathrm{ml}$., thus allowing a 300-fold reduction at each transfer, so that the blanks of the second should have contained about $10 \mathrm{~m} \mu \mathrm{g} / \mathrm{l}$. With Hemiselmis and the dinoflagellates, however, an inoculum of $0.2-0.3 \mathrm{ml}$. was advisable which only allowed a 20 -fold reduction, with the consequence that four transfers were necessary to deplete the blanks to the same extent.

Transfers were made from the blanks. To the other cultures the vitamin was added initially in the form of the complete molecule (0.1 mg/1.), but later

TABLE 3. SERIAL TRANSFER EXPERIMENTS WITH THIAMINE

(-, blank; +, with o. I mg/l. thiamine. OD $\times$ roo. $)$

\begin{tabular}{|c|c|c|c|c|c|c|c|c|c|c|c|c|c|}
\hline \multirow{3}{*}{$\begin{array}{c}\text { Transfer } \\
\text { No. }\end{array}$} & \multicolumn{13}{|c|}{ Species } \\
\hline & \multicolumn{2}{|c|}{$\begin{array}{l}\text { Nanno- } \\
\text { chloris }\end{array}$} & \multicolumn{2}{|c|}{$\begin{array}{c}\text { Phaeodac- } \\
\text { tylum }\end{array}$} & \multicolumn{2}{|c|}{$\begin{array}{l}\text { Mono- } \\
\text { chrysis }\end{array}$} & \multicolumn{2}{|c|}{$\begin{array}{c}\text { Prymnes- } \\
\text { ium }\end{array}$} & \multicolumn{2}{|c|}{$\begin{array}{l}\text { Syraco- } \\
\text { sphaera }\end{array}$} & \multicolumn{2}{|c|}{$\begin{array}{c}\text { Micro- } \\
\text { glena }\end{array}$} & $\begin{array}{c}\begin{array}{c}\text { Hemisel- } \\
\text { mis }\end{array} \\
\text {. }\end{array}$ \\
\hline & - & + & - & + & - & + & - & + & - & + & - & + & + \\
\hline I & 66 & 68 & 57 & 70 & 122 & IIO & 80 & 92 & 44 & $4 I$ & 35 & 52 & $32 \quad 70$ \\
\hline 2 & 92 & 92 & 8 & Ioo & 30 & 140 & 0 & & I6 & 39 & II & 48 & 7 IIo \\
\hline 3 & IIO & 100 & 92 & 89 & 4 & 150 & 2 & 80 & 27 & 59 & 22 & 43 & 2105 \\
\hline
\end{tabular}

TABLE 4. SKELETONEMA COSTATUM, SERIAL TRANSFER EXPERIMENTS $(\mathrm{OD} \times 100$. standard errors in parentheses, $n=5$.)

\begin{tabular}{|c|c|c|c|}
\hline & & Treatment & . \\
\hline $\begin{array}{c}\text { Transfer } \\
\text { no. }\end{array}$ & Blank & $\begin{array}{c}\mathrm{I} \cdot 0 \mathrm{mg} / \mathrm{l} . \\
\mathrm{Na}_{2} \mathrm{~S}_{9} \mathrm{H}_{2} \mathrm{O}\end{array}$ & $\begin{array}{l}\text { O. I mg/l. } \\
\text { thiamine }\end{array}$ \\
\hline 2 & $27(5 \cdot 4)$ & 2 I $(9.0)$ & $40(3 \cdot 7)$ \\
\hline 3 & $39(\mathrm{I} \cdot 0)$ & $39(0.8)$ & $39(0.7)$ \\
\hline 4 & $0.4(0.4)$ & $29(I \cdot 25)$ & $2 I(3.4)$ \\
\hline 5 & $2 \mathrm{I}(0.7)$ & $30(1.05)$ & $32(\mathrm{I} \cdot \mathrm{I})$ \\
\hline
\end{tabular}

TABLE 5. DINOFLAGELLATE SERIAL TRANSFER EXPERIMENTS

(Numbers per $\mathrm{mm}^{3}$.)

\begin{tabular}{|c|c|c|c|c|c|}
\hline \multirow{3}{*}{$\begin{array}{c}\text { Transfer } \\
\text { no. }\end{array}$} & \multicolumn{5}{|c|}{ Treatment } \\
\hline & Blank & Thiamine & $\begin{array}{l}\text { Thiazole }+ \\
\text { pyrimidine }\end{array}$ & Thiazole & Pyrimidine \\
\hline & \multicolumn{5}{|c|}{ Oxyrrhis marina } \\
\hline I & 32 & II9 & II3 & 125 & 25 \\
\hline 2 & 8 & 73 & 129 & 72 & 5 \\
\hline \multicolumn{6}{|c|}{ Peridinium trochoideum } \\
\hline 2 & 9 & 8 & 13 & I3 & 7 \\
\hline 3 & 6 & 8 & 6 & 13 & 3 \\
\hline 4 & 9 & 7 & 8 & 6 & 9 \\
\hline \multicolumn{6}{|c|}{ Glenodinium foliaceum } \\
\hline 2 & 34 & 26 & 27 & 30 & 24 \\
\hline 3 & 20 & 28 & 27 & 33 & 28 \\
\hline 4 & - & 33 & 39 & 28 & $3 I$ \\
\hline 5 & 28 & 21 & 26 & 26 & 25 \\
\hline
\end{tabular}


the molecule was 'split' into its components, 4 -methyl-5- $\beta$-hydroxyethylthiazole and 2-methyl-4-amino-5-aminomethyl-pyrimidine, and the following treatments given: $(a)$ blank, $(b)$ complete molecule, $(c)$ thiazole and pyrimidine in equal amounts, $(d)$ thiazole alone, and $(e)$ pyrimidine alone.

The results of the transfer experiments are shown in Tables $3-5$.
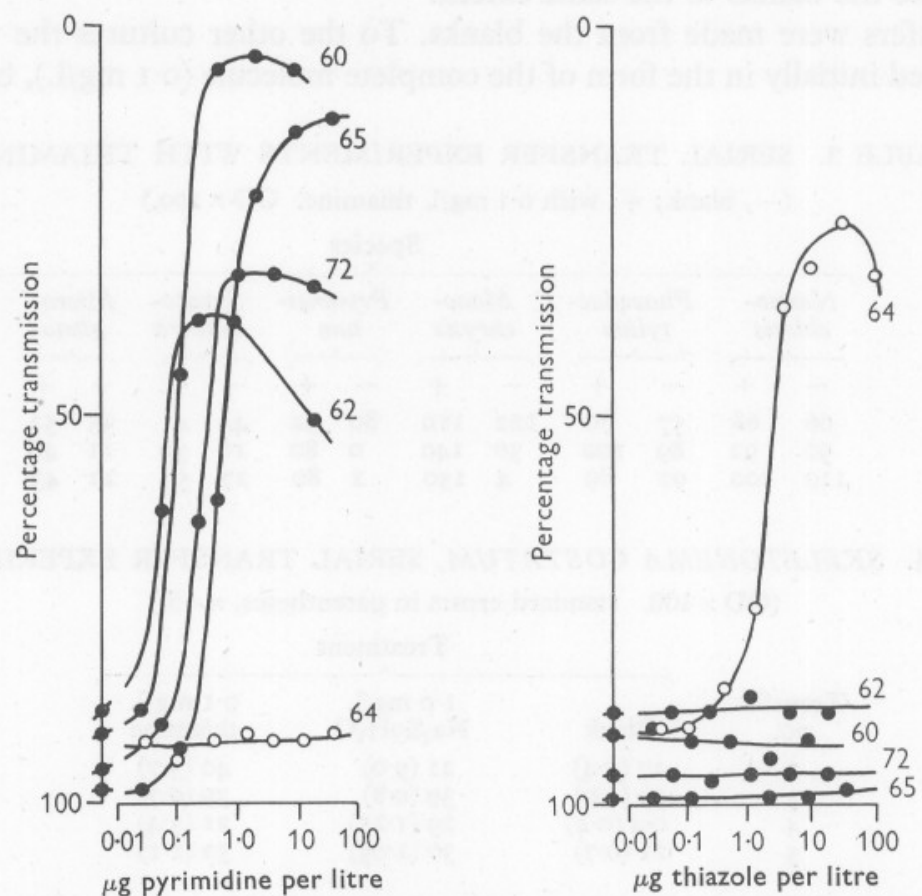

Fig. I. Response to pyrimidine (left hand) and thiazole (right hand). 60, Monochrysis lutheri; 62, Syracosphaera elongata; 64, Hemiselmis virescens; 65, Prymnesium parvum; 72, Microglena arenicola.

\section{Dose/response experiments}

Where time and the material allowed the transfer experiments were confirmed by dose/response experiments in which was measured yield in response to graded doses of thiamine and its component parts. Response curves for the chrysomonads and Hemiselmis to pyrimidine and to thiazole are set out in Fig. I.

\section{DISCUSSION}

Table 6 summarizes the results and includes data of other requirements, notably that for $\mathrm{B}_{12}$. Previous reports regarding Phaeodactylum, Nannochloris and Skeletonema are confirmed (Peach \& Drummond, 1942; Hutner, I948; Droop, $1955 a, b)$. All but two of the species under discussion in this paper 
are of littoral or supra-littoral origin, the pelagic strains being Skeletonema and Peridinium trochoideum: neither had an absolute requirement for thiamine.

Skeletonema has been rather difficult to work with in defined media, because the vigour of cultures seems to depend to a large extent on such factors as $\mathrm{pH}$, oxygen tension and the state of the inoculum-whether, for instance, it is in the exponential or stationary phase of growth, and its relation to the auxospore cycle. Under favourable conditions growth is quite independent of thiamine, and at such times thiamine does happen to be beneficial (as in the fourth transfer, Table 4) it can always be replaced by inorganic sulphide;

TABLE 6. SUMMARY OF RESULTS, WITH DATA ON OTHER HETEROTROPHIC TENDENCIES

\begin{tabular}{|c|c|c|c|c|}
\hline & $\begin{array}{l}\text { Requirement } \\
\text { for } \\
\text { thiamine }\end{array}$ & $\begin{array}{l}\text { Portion of } \\
\text { vitamin } \\
\text { required }\end{array}$ & $\begin{array}{l}\text { Requirement } \\
\text { for } \\
\text { vitamin } B_{12}\end{array}$ & Other heterotrophic tendencies \\
\hline $\begin{array}{l}\text { Chrysophyceae } \\
\text { Monochrysis } \\
\text { Prymnesium } \\
\text { Syracosphaera } \\
\text { Microglena }\end{array}$ & + & Pyrimidine & (5) & $\left\{\begin{array}{r}\text { Can utilize some amino acids } \\
\text { as N source (Droop, I955a) }\end{array}\right.$ \\
\hline $\begin{array}{l}\text { Chlorophyceae } \\
\text { Nannochloris } \\
\text { Bacillariophyceae } \\
\text { Phaeodactylum }\end{array}$ & - & - & - & $\left\{\begin{array}{l}\text { Can utilize some amino acids as } \\
\mathrm{N} \text { source (Droop, r955a) }\end{array}\right.$ \\
\hline Skeletonema & - & - & + & $\begin{array}{l}\text { Organic compounds sometimes } \\
\text { stimulatory in an unspecific } \\
\text { way (Droop, 1957) }\end{array}$ \\
\hline $\begin{array}{l}\text { Cryptophyceae } \\
\text { Hemiselmis } \\
\text { Dinophyceae }\end{array}$ & $t$ & Thiazol & & Amino N obligatory (Droop, \\
\hline Oxyrrhis & + & & $?$ & $\begin{array}{l}\text { Amino } \mathrm{N} \text { obligatory; acetate as } \\
\mathrm{C} \text { source; phagotrophic in } \\
\text { Nature; other B vitamins } \\
\text { (unpublished data) }\end{array}$ \\
\hline $\begin{array}{l}\text { Glenodinium } \\
\text { Peridinium }\end{array}$ & - & - & + & ? \\
\hline
\end{tabular}

consequently, it is unlikely that the vitamin is functioning here in this same way as in other organisms. Incidentally, neither Hemiselmis nor Oxyrrhis could utilize inorganic sulphide in place of thiazole. The significance of sulphur-containing compounds in diatom growth has been discussed by Harvey (1939, 1955); Lewin (1954) and Droop (1957)

The results appertaining to two photosynthetic dinoflagellates, Peridinium trochoideum and Glenodinium foliaceum (Table 5) are not completely satisfactory owing to the lightness of growth normally obtained with these two species. It is noted, therefore, simply that no requirement was demonstrable even after four transfers. On the other hand, a requirement for vitamin $\mathrm{B}_{12}$ became apparent on the first transfer and it was not possible to carry either species through more than two transfers in $\mathrm{B}_{12}$-free media.

The four chrysomonads all responded to the pyrimidine half of the vitamin, whereas Hemiselmis and Oxyrrhis responded to the thiazole half (Fig. I). 
Possibly this represents a phyletic difference between the Chrysophyta and Pyrrophyta, though it is early to tell. With the exception of Oxyrrhis, all the species which proved to need thiamine had already been found to have a requirement for vitamin $B_{12}$ (Droop, I957), but the reverse was not the case.

The Chrysomonads are quite indifferent to the presence or absence of thiazole in the medium, so their response to pyrimidine can be regarded as simple. Hemiselmis and Oxyrrhis, on the other hand, appear to obtain some benefit from pyrimidine: pyrimidine does not support growth and, in the presence of thiazole, affects yield only slightly, nevertheless, Hemiselmis bleaches more quickly in its absence and Oxyrrhis fails to produce the fine pink colour characteristic of heavy healthy cultures.

It is not possible to arrive at more than a rough estimate of the magnitude of the thiamine requirement from dose/response curves based on optical measurements (Fig. I). Furthermore, the basal medium $\mathrm{S}_{50}$ was developed to suit Monochrysis and was not necessarily that most suitable for the other species. Half-maximal growth of the pyrimidine-requiring organisms appeared to be given by $100-300 \mathrm{~m} \mu \mathrm{g} / \mathrm{l}$. pyrimidine or thiamine; half-maximal growth of both Oxyrrhis and Hemiselmis (requiring thiazole) by ten times as much, i.e. $2000 \mathrm{~m} \mu \mathrm{g} / 1$., thiazole or thiamine. Such a difference in magnitude in thiamine requirement between pyrimidine and thiazole-requiring species has rather interesting implications should it prove to be real and of general occurrence. It suggests either that thiamine has a different function according to whether the requirement is met by one-half of the vitamin or by the other, or, alternatively, that the functions of pyrimidine and thiazole are divorced from each other and that the function of thiamine here is merely to supply either thiazole or pyrimidine as the case may be. Which alternative is biochemically less improbable it is difficult to say. On the other hand, it is possible that thiazole is merely more labile than pyrimidine.

\section{SUMMARY}

The requirement for thiamine was examined in eleven marine protists of littoral, supra-littoral or neritic origin. Six were found to have an absolute requirement for the vitamin.

The thiamine-requiring Chrysophyta responded to the pyrimidine half of the vitamin, whereas the two thiamine-requiring Pyrrophyta responded to the thiazole half.

All the species requiring thiamine were auxotrophic with respect to at least one other factor (usually vitamin $\mathrm{B}_{12}$ ).

For half-maximal growth, species responding to pyrimidine required 100$300 \mathrm{~m} \mu \mathrm{g} / \mathrm{l}$. pyrimidine or thiamine and species responding to thiazole $2000 \mathrm{~m} \mu \mathrm{g} / 1$. thiazole or thiamine. 


\section{REFERENCES}

Droop, M. R., I953a. On the ecology of flagellates from some brackish and fresh water rock pools of Finland. Acta bot. fenn., No. 51, 52 pp.

— 1953b. Phagotrophy in Oxyrrhis marina. Nature, Lond., Vol. 172, p. 250.

1954. Cobalamin requirement in Chrysophyceae. Nature, Lond., Vol. I74, p. 520.

_ I 955 a. Some new supra-littoral Protista. F. mar. biol. Ass. U.K., Vol. 34, pp. 233-45.

I955b. A pelagic marine diatom requiring Cobalamin. 7. mar. biol. Ass. U.K., Vol. 34, pp. 229-31.

- 1957. Auxotrophy and organic compounds in the nutrition of marine phytoplankton. F. gen. Microbiol., Vol. 16, pp. 286-93.

HARVEY, H. W., I939. Substances controlling the growth of a diatom. F. mar. biol. Ass. U.K., Vol. 23, pp. 499-519.

- 1955. The Chemistry and Fertility of Sea Water, 224 pp. Cambridge University Press.

HUTNER, S. H., I948. Essentiality of constituents of sea water for growth of a marine diatom. Trans. N.Y. Acad. Sci., Vol. I0, pp. I36-41.

LEWIN, J. C., 1954. Silicon metabolism in diatoms. I. Evidence for the role of reduced sulfur compounds in silicon utilization. F. gen. Physiol., Vol. 37, pp. 589-99.

LwoFf, A. \& LEDERER, E., I935. Remarques sur 'l'extrait de terre' envisagé comme facteur de croissance pour les flagellés. C.R. Soc. Biol., Paris, T. I19, pp. 971-3.

MCLAUghlin, J. J. A., I958. Euryhaline chrysomonads: nutrition and toxigenesis in Prymnesium parvum with notes on Isochrysis galbana and Monochrysis lutheri. 7. Protozool, Vol. 5, pp. 75-80.

Peach, E. A. \& Drummond, J. C., 1924. On the culture of the marine diatom Nitzschia closterium (F) minutissima, in artificial sea water. Biochem. F., Vol. I8, pp. $464-68$.

Provasoli, L., McLaughlin, J. J. A. \& Droop, M. R., I957. The development of artificial media for marine algae. Arch. Mikrobiol., Bd. 25, pp. 392-428.

Provasoli, L. \& PintneR, I. J., I953. Ecological implications of in vitro nutritional requirements of algal flagellates. Ann. N.Y. Acad. Sci., Vol. 56, pp. 839-5I.

SNell, E. E., 1951. Bacterial nutrition-chemical factors. In Bacterial Physiology, ed. C. W. Werkman and P. W. Wilson. 707 pp. New York: Academic Press Inc. 